\title{
Pulp Response to Lyophilized Bone in Rat Teeth
}

\author{
Antonia Alcaina Lorente ${ }^{1, *}$, Olga Cortés Lillo ${ }^{1}$, Miguel Ángel Gómez Sánchez ${ }^{2}$, Manuel Canteras Jordana ${ }^{1}$ \\ ${ }^{1}$ Department of Pediatric Dentistry, Medical and Dental School, University of Murcia, Spain \\ ${ }^{2}$ Veterinary School, University of Murcia, Spain
}

Copyright $\mathrm{O} 2016$ by authors, all rights reserved. Authors agree that this article remains permanently open access under the terms of the Creative Commons Attribution License 4.0 International License

\begin{abstract}
Background: This article will review different materials for the treatment of pulps of primary and young permanent teeth. However, innovations in materials and advances in biology suggest that there may soon be a convergence of therapies for teeth of either dentition needing pulp treatment. Objectives: The objective of this study was evaluated the pulp and liver response to biocompatible agents such as lyophilized bone in comparison with classical formocresol. Materials and Methods: Treatment was applied to the upper right and left first molar of each animal, for a total of 120 teeth. Six groups were established according to the agent used and the time elapsed (30, 45 and 60 days). In each group five livers were selected, and a control group subjected to no treatment was also evaluated. At the end of the study the rats were sacrificed and the samples were processed for histological evaluation. Analysis of variance (ANOVA) for repeated measures was used. Results: Dentinal bridge formation and reparative dentin reached higher values in the group treated with lyophilized bone. The formocresol treatment group showed increased inflammation and necrosis. Conclusions: Lyophilized bone afforded improved pulp tissue response. No histological evidence of liver damage was observed in any of the hepatic samples studied.
\end{abstract}

Keywords Pulpotomy, Formocresol, Lyophilized Bone

\section{Introduction}

This article will review different materials for the treatment of pulps of primary and young permanent teeth and describe new therapies that might supplant them in the future.

A pulpotomy in a young permanent tooth is undertaken to promote apexogenesis; under these conditions, retention of the vitality of the radicular pulp is imperative. However, innovations in materials and advances in biology suggest that these may soon be a convergence of therapies for teeth of either dentition needing pulp treatment [1].

Several medicaments have been used to devitalize remaining pulp or maintain pulp vitality an promote healing. Based on pulpal biocompatibility and good sealing ability, a growing interest in more biocompatible materials promotes lyophilized bone as an alternative to tradicional medicaments. Lyophized bone can preserve pulpal health and promote healing with pulp regeneration in primary and permanent teeth. This material has been employed as an off-the-shelf grafting in periodontal osseous defects[2].

Of the different agents developed for application in primary dentition pulpotomy, formocresol (FMC) is the most widely used [3], though the use of this substance has been seriously questioned in view of the possible toxic effects of FMC upon organs such as the kidneys and liver [3, 4], as well as its mutagenic and carcinogenic potential [5] and immune response inducing capacity [6] .

For these reasons a number of alternatives to FMC have been developed, such as glutaraldehyde [7] and ferric sulfate [8, 9], biocompatible materials such as collagen [10], lyophilized bone $[2,11,12]$ and bone forming morphogenetic proteins [13], or techniques such as electrocoagulation [14] and laser [15]. The aim of these materials and techniques is to preserve remmant pulp tissue viability and function, and facilitate its repair.

Although the systemic toxicity of FMC has not been investigated in humans, animal studies have shown the substance to distribute systemically $[16,17,18]$.

Lyophilized bone is biocompatible and may afford positive results in application to pulpotomies.

Fadavi et al. [2] performed pulpotomies with lyophilized bone in deciduous and permanent teeth of Cynomalagus monkeys. The pulp response was evaluated after 12 weeks, comparing the efficacy of the agent with that of calcium hydroxide and FMC. After three months, calcification was observed beneath the amputation site in the teeth treated with lyophilized bone. The odontoblastic cells were normal in appearance, with the occasional presence of chronic inflammatory cells.

Posteriorly, in a study involving monkeys carried out by the same authors, the previous results were corroborated after 6 weeks of treatment with lyophilized bone [12] .

The present study was made to evaluate pulp and liver response to biocompatible agents such as lyophilized bone in 
comparison with classical FMC.

\section{Materials and Methods}

The study involved 60 female Sprague-Dawley rats weighing 150-250 g. Treatment was applied to the upper right and left first molar of each animal, for a total of 120 teeth. Six groups of 10 animals each (20 teeth) were established according to the agent used and the time elapsed (30, 45 and 60 days). Pulp exposure was carried out with FMC treatment followed by zinc oxide-eugenol (ZOE) paste, or with lyophilized bone likewise followed by ZOE paste.

In order to evaluate the toxic potential of the materials used, the rat livers were subjected to histological study. Five livers were selected corresponding to each time interval (30, 45 and 60 days). A control group subjected to no pulpotomy treatment was also included to evaluate and compare possible changes at hepatic level.

In all procedures the animals were anesthetized by intramuscular inyection of Ketamine (Ketolar TM Parke-Davis, Morris Plains) at approximately $30 \mathrm{mg} / \mathrm{kg}$. Acces to the maxillary first molars was obtained by use of an operating table. The tongue and cheeks were reflected from the operation field.

A small H7-008 Komet piriform tungsten drill was used to open the pulp chamber [9]. The chamber was accessed from the occlusal surface.

If there was marked hemorrhage, an endodontic paper point was used to remove the excess blood. Some exposures were nonbleeding or had very little bleeding.

In the groups treated with formocresol, paper points moistened with $20 \%$ dilution of formocresol were placed in contact with pulpal stumps for five minutes as described by Massler and Mansukhani [19]. The formocresol used was Buckley's formocresol, diluted with glycerol and water, in a $1: 5$ ratio.

In the case of the groups treated with biocompatible lyophilized bone (Bioss $\left.{ }^{\circledR}\right)$, the latter was applied to the exposed chamber with a spatula.

After application of the two materials, ZOE paste was deposited (2:1 powder/liquid proportion) without applying excessive pressure.

Silver amalgam then was packed into the preparations to avoid the loss of the base.

The rats were sacrificed by an ether overdose after the corresponding evolutive periods (30, 45 and 60 days), with dissection of the hemimaxilla and liver for fixation in $10 \%$ formalin solution and histological processing.

The sections were examined under a light microscope to assess pulpal response. Coronal third, middle third and apical third of the radicular pulp were examined histologically by the oral pathologist who did not know the treatment received or the post treatment intervals. The evaluation was performed according to the criteria by Horsted et al. [20] and modified by Fuks et al. [7]. The criteria are:

- Degree of inflammation
- Pulpal necrosis

- Fibrotic tissue

- Reparative dentin and dentin bridge

- Presence and regularity of odontoblastic layer

Liver tissue response was in turn scored according to the observed degree of cell degeneration according to the criteria adopted by Trigo [21]:

$0=$ no degeneration;

$1=$ slight degeneration;

$2=$ moderate degeneration;

$3=$ severe degeneration.

A descriptive statistical study was made of each variable, with calculation of the mean and standard deviation. Analysis of variance (ANOVA) for repeated measures was used to establish comparisons between groups.

The experimental study fulfilled the ethical and legal conditions set out in Royal Decree 233/1988 of March and the Order of 13 October, 1989, on the protection of animals used for experimental and scientific purposes. The experiments were carried out in the animalarium of the University of Murcia (licence ${ }^{0} 300302 \mathrm{AB}$ ).

\section{Results}

The samples obtained were examined under the light microscope to assess pulp and liver response to the agents used in the pulpotomies.

\section{0 days}

FMC-ZOE. The most characteristic finding was a necrotic zone immediately beneath the amputation site, followed by acute inflammation with the presence of polymorphonuclear cells and fewer lymphocytes.

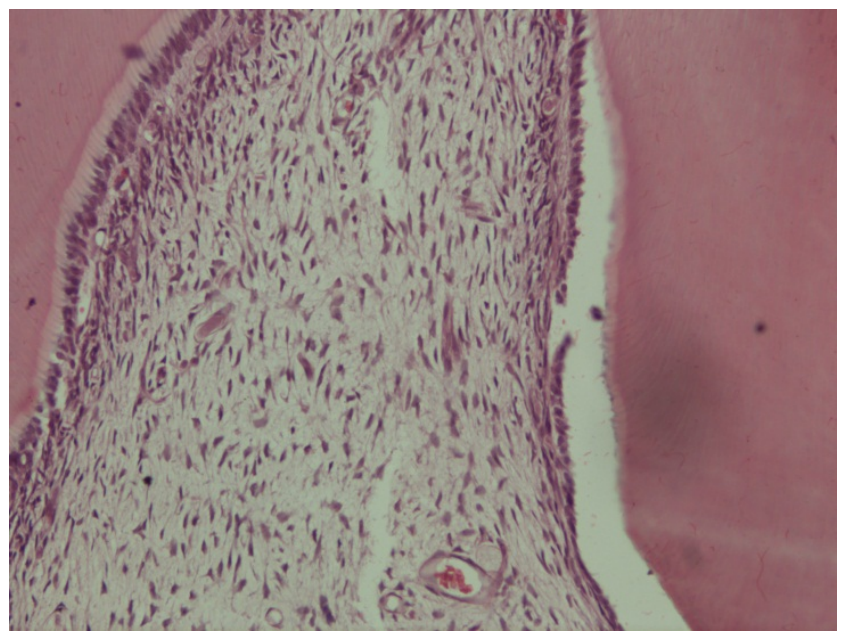

Figure 1. Histological root pulp response 30 days after treatment with lyophilized bone. Presence of a regular odontoblastic layer (ROL). Descalcification technique, hematoxylin-eosin (HE), x10.

Lyophilized bone-ZOE. With minor variations, most of the sections below the amputation site presented tissue with 
initial calcification, slight inflammation in the middle third with the proliferation of fibroblasts and the presence of a collagen fiber network. This moderate inflammation further decreased towards the lower third, with the presence of a regular odontoblastic layer (Fig 1).

\section{5 days}

FMC-ZOE. Inflammation was seen to progress towards the lower third.

Lyophilized bone-ZOE. A complete or partial calcium barrier was identified beneath the exposure site. The lower third remained vital with occasional visible inflammatory cells and the presence of reparative dentin along the walls of the root canal.

\section{0 days}

FMC-ZOE. Increased inflammation was observed in the lower third, with an irregular odontoblastic layer. Some samples exhibited reparative dentin formation along with dystrophic calcifications (Fig 2).

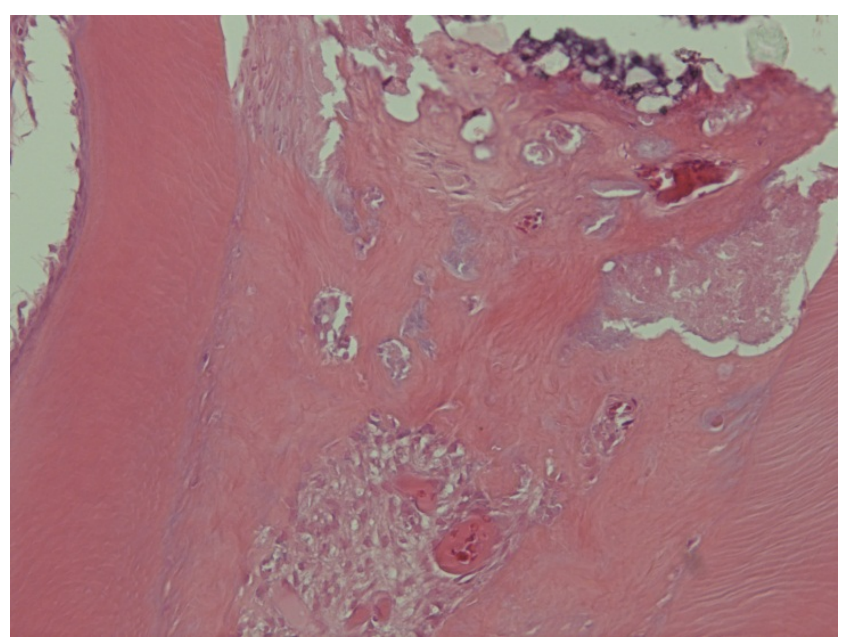

Figure 2. Histological root pulp response 60 days after treatment with formocresol. Partial necrosis of the lower third and dystrophic calcifications (DC). Decalcification technique, hematoxylin-eosin (HE), x10.

Lyophilized bone-ZOE. A characteristic finding was the formation of reparative dentin along the canal, with the presence of dentinal bridges in some samples (Fig 3).

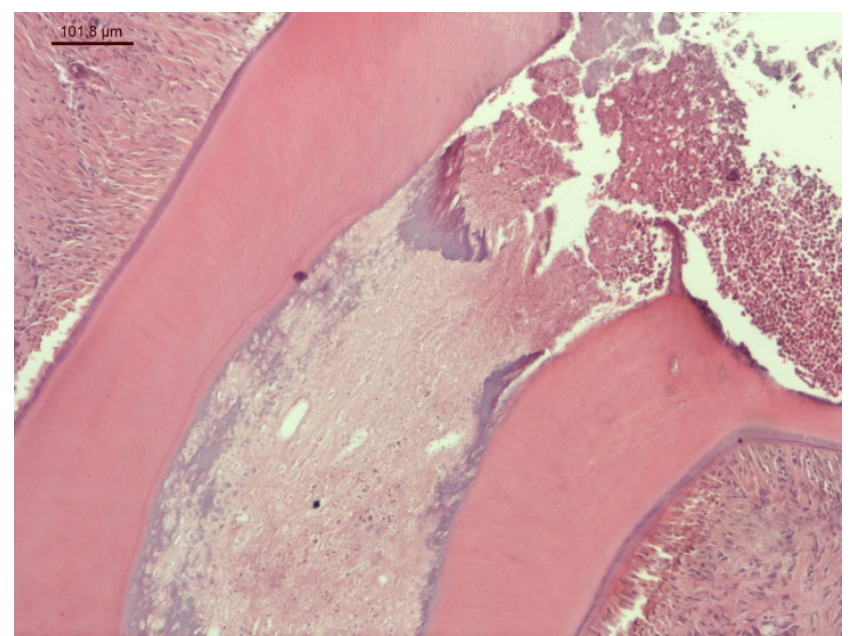

Figure 3. Histological root pulp response 60 days after treatment with lyophilized bone. Formation of a dentinal bridge (DB) in the upper third. Decalcification technique, hematoxylin-eosin (HE), x20.

In general, the FMC treatment group showed greater inflammation - significant differences being established between the two treatment modalities between the different upper, middle and lower locations, and according to the evolutive time involved $(\mathrm{p}=0.0256)($ Table 1$)$.

Table 1. Descriptive statistical for the degree of inflammation. Mean and standard deviations.

\begin{tabular}{|c|cc|cc|cc|}
\hline \multirow{2}{*}{ Treatment/Time } & \multicolumn{2}{|c|}{30 days } & \multicolumn{2}{c|}{45 days } & \multicolumn{2}{c|}{60 days } \\
& mean & SD & mean & SD & Mean & SD \\
\hline Formocresol & 1.64 & 0.51 & 1.73 & 0.42 & 2.03 & 0.46 \\
\hline $\begin{array}{c}\text { Lyophilized } \\
\text { bone }\end{array}$ & 1.53 & 0.44 & 1.64 & 0.55 & 1.68 & 0.47 \\
\hline
\end{tabular}

In the lyophilized bone group an increased presence of dentinal bridges was recorded. There were significant differences between the two treatment groups, with variations according to the time elapsed $(p=0.00005)$ (Table 2).

Table 2. ANOVA for the degree of dentinal bridge and reparative dentin;

\begin{tabular}{|c|c|c|c|c|}
\hline SOURCE & $\begin{array}{c}\text { SUM OF } \\
\text { SQUARES }\end{array}$ & $\begin{array}{c}\text { MEAN } \\
\text { SQUARE }\end{array}$ & F & P-VALUE \\
\hline Treatment & 10.55946 & 10.55946 & 70.73 & $0.00005 *$ \\
\hline Time & 7.13051 & 3.56525 & 23.88 & $0.00005 *$ \\
\hline Treatment-Time & 6.16717 & 3.08359 & 20.66 & $0.00005 *$ \\
\hline
\end{tabular}




\section{Liver tissue}

No characteristic lesions indicative of liver damage were observed in any of the study groups (Fig 4).

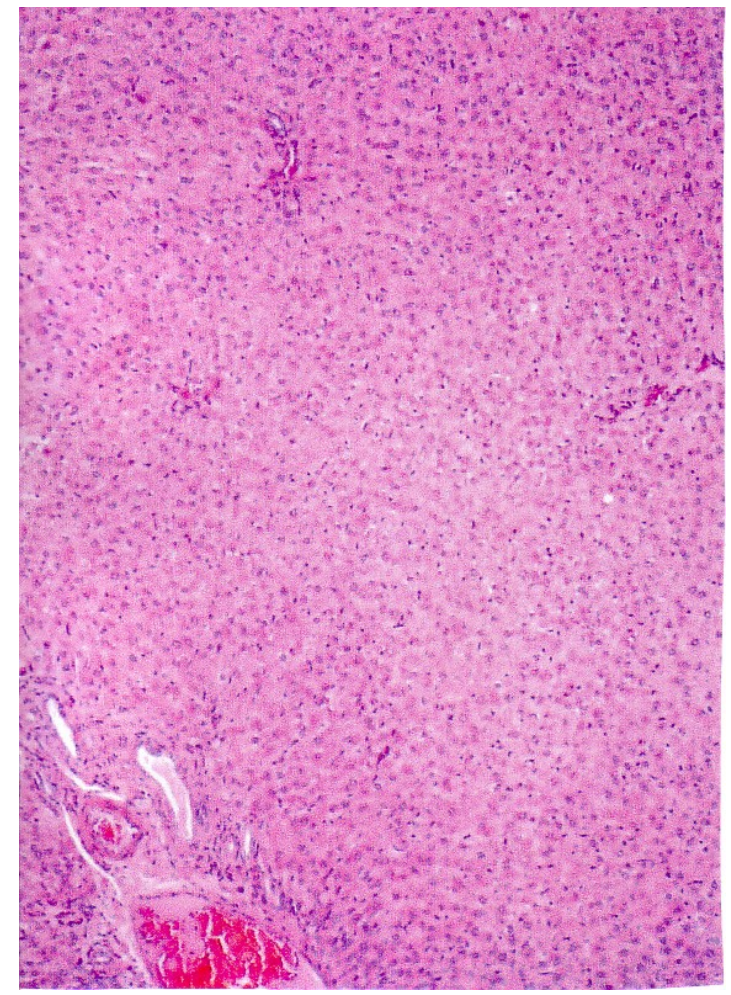

Figure 4. Histological liver section corresponding to the lyophilized bone group after 45 days. No evidence of hepatocyte damage or degeneration is observed. Hematoxylin-eosin (HE), x10.

\section{Discussion}

Several materials have been used to desvitalize remaining pulp or maintain pulp vitality and promote healing. Liophilized bone, as a pulpotomy medicament was used in the present study and its histological success was assed.

Ideally, the agent used in performing pulpotomies should be innocuous for the pulp tissue and for the surrounding structures $[1,22]$. Despite the great efficacy of formocresol (FMC) in application to pulpotomy and its widespread use, controversy has developed over its possible toxic effects and the use of this agent is decreasing considerably worldwide.

Bearing in mind our objetives, its was important to consider a work with experimental animals, in other to value the pulp response.

Regarding the evolutive period, earlier studies [9, 23,24] have evaluated pulp response after one, two, three and four weeks, and Berman and Massler [25] observed dentinal bridge formation in the treated teeth after 21-28 days. In our study we decided to extend the evolutive period to 30,45 and 60 days, with the aim of allowing full pulp response development and confirming the absence of no further changes in the pulp tissue.

In our study, the FMC treated animals showed a clear upper necrotic region, beneath which a scantly cellular zone characterized by an inflammatory infiltrate was observed; reparative dentin was observed in few samples, along with dystrophic calcifications. These results coincide with those of Magnusson [26] and Alacam [27]. On the other hand, we agree with Fuks et al. ${ }^{28}$ in that the odontoblastic layer exhibits an irregular distribution in the middle region, while the regular disposition is preserved in the lower zone.

The use of lyophilized bone afforded better pulp tissue response and less inflammation. These findings agree with the observations reported by Fadavi et al. [2], who applied lyophilized bone in monkey teeth.

It should be taken into account that zinc oxide eugenol is not the ideal option for pulpotomy, since it may induce added inflammation. Both the beneficial effects of zinc oxide eugenol and its inconveniences are attributable to the presence of eugenol, which can diffuse through the pulp component after release from the paste [29]. However, the eugenol in sett ZOE is bound mostly and unavailable to exert its toxic effects [30].

Although the systemic toxicity of FMC has not been investigated in humans, animal studies have shown the substance to distribute systemically $[31,32]$.

Ranly [18] in a study in rats involving the use of $19 \%$ formaldehyde, concluded that two hours after pulpotomy, $30 \%$ of the formaldehyde administered is distributed systemically. In a second part of his study [33] the dose absorbed systemically as a result of a single pulpotomy was found to be $0.38 \mu$ moles. These results do not coincide with those reported by Myers et al. [32], who observed histological changes in both liver and kidney. The methodology involved (16 pulpotomies in a single animal) may also have played a role.

The histological analysis of the liver samples in the groups studied showed no evidence of liver damage and no necrosis in any case. Nevertheless, the samples did show different degrees of cellular degeneration. In this sense, water was found to be present within the hepatocyte cytoplasm, producing a clearer zone around the nucleus. The degenerative changes seen in some livers were nonspecific and may have been a result of histological preparation of the specimens after application of the fixation agent, or a consequence of alterations inherent to the diet provided. Ether sacrifice may also have produced such alterations.

Studies with biochemical markers would be needed to establish whether toxicity mediated by the material employed effectively exists, with the confirmation of liver lesions.

It should also be pointed out that differences in methodology, study subjects (humans, rats, monkeys, dogs, etc.), evolutive times, drug concentrations and evaluation parameters all make it extremely difficult to compare different studies. On the other hand, despite the similarity of the organs investigated in humans and rats, the results obtained in the latter species cannot be extrapolated to man thereby precluding the drawing of firm conclusions.

The bone grafting has osteogenic properties and readly 
incorporation to the tissue. However, the acquisition of autogenous bone can add risks to the patient, including additional surgical injury. Previous studies indicate the increased bone resorption rate of this type of material as a disadvantage. The bacterial contamination of bone obtained from the mouth with a bone collector has to be anticipated. Density is different in bone dust. Bone dust could not create new bone, whereas bone particles were capable of preserving viability [34].

The results obtained with lyophilized bone are promising and satisfy the requirements for use in pulpotomies, since it is a biological material without toxic potential that offers both reparatory and regenerative properties.

Bovine bone has practically unlimited availability and great physicochemical and structural similarity to human bone. Several studies have confirmed this product presents excellent biocompatibility, with characteristics similar to natural bone [35]. A limitation may be its cost, however, and laboratories should attempt to simplify obtainment of the material in order to market a more accessible product. In any case, other agents (morphogenetic proteins) are also very interesting in this field, and attention should furthermore focus on the existence of other materials which while not biocompatible do exhibit less toxicity - such as ferric sulfate [8] or mineral trioxide aggregate [36-38], which offer promising perspectives. Further long term clinical evaluation of mineral trioxide aggregate as a pulpotomy agent needed carried out.

\section{Conclusions}

Lyophilized bone afforded improved pulp tissue response. No histological evidence of liver damage was observed in any of the hepatic samples studied.

\section{Acknowledgements}

The authors gratefully acknowledge the support of the Veterinary Faculty.

\section{REFERENCES}

[1] Fuks AB. Current concepts in vital primary pulp theraphy. Eur J Paediatr Dent 2002; 3: 115-20.

[2] Fadavi S, Anderson AW, Punwani IC. Freeze-dried bone in pulpotomy procedures in monkey. J Pedod 1989; 13: 108-22.

[3] Fuks AB, Eidelman E. Pulp therapy in the primary dentition. Curr Opin Dent 1991; 1: 556-63.

[4] Ketley CE, Goodman JR. Formocresol toxicity: is there a suitable alternative for pulpotomy of primary molars? Int J Pediatric Dent 1991; 1: 67-72.

[5] Lewis B. The obsolescence of formocresol. J Calif Dent Assoc
2010; 38(2): 102-7 .

[6] Wu MK, Wang ME. Antibody formation to dog pulp tissue altered by a paste containing paraformaldehyde. Int Endod J 1989; 22: 133-37.

[7] Fuks AB, Bimstein E, Michaeli Y. Glutaraldehyde as a pulp dressing after pulpotomy in primary teeth of baboon monkeys. Pediatr Dent 1986; 8: 32-6.

[8] Fei AL, Udin RD, Johnson R. A clinical study of ferric sulfate as a pulpotomy agent in primary teeth. Pediatr Dent 1991; 13: 327-32.

[9] Cortés O, Boj JR, Canalda, C, Carreras M. Pulpal tissue reaction to formocresol vs. ferric sulfate in pulpotomized rat teeth. J Clin Pediatr Dent 1997 ; 21: 247-52.

[10] Fuks AB, Jones PC, Michaeli Y. et al. Pulp response to collagen and glutaraldehyde in pulpotomized primary teeth of baboon. Pediatr Dent 1991; 13: 142-50.

[11] Salako N, Joseph B, Pitwik P. Comparison of bioactive glass, mineral trioxide aggregate, ferric sulfate, and formocresol as pulpotomy agents in rat molar. Dent Traumatol 2003; 19: 314-20.

[12] Fadavi S, Anderson AW. A comparison of the pulpal response to freeze-dried bone, calcium hydroxide, and zinc oxide-eugenol in primary teeth in two cynomolgus monkeys. Pediatr Dent 1996; 18: 52-6.

[13] Rutherford RB, Wahle J, Tucker M, Tucker M, Rueger D, Charette M. Induction of reparative dentine formation in monkeys by recombinant human osteogenic protein-1. Arch Oral Biol 1993; 38: 571-74.

[14] Bahrololoomi Z, Moeintaghavi A, Emtiazi M, Hosseini G. Indian J Dent Res 2008; 19(3): 219-23.

[15] Odabas ME, Bodur H, Baris E, Demir C. Clinical, radiographic, and histopathologic evaluation of $\mathrm{Nd}$ : YAG laser pulpotomy on human primary teeth. J Endod 2007; 33(4): 415-21.

[16] Myers DR, Shoaf HK, Duk TR et al. Distribution of 14C-formaldehyde after pulpotomy with formocresol. J Am Dent Assoc 1978; 96:805-13.

[17] Pashley EL, Myers DR, Pashley DH et al. Systemic distribution of $14 \mathrm{C}$ - formaldehyde from formocresol-treated pulpotomy sites. J Dent Res 1980; 59: 603-8.

[18] Ranly DM. Assessment of the systemic distribution and toxicity of formaldehyde following pulpotomy treatment: part one. J Dent Child 1985; 52 : 431-4.

[19] Massler M, Mansukhani N. Effects of formocresol on the dental pulp. J Dent Child 1959; 26: 277-82.

[20] Horsted P, El-Ahark K, Langeland K. Capping of monkey pulps with dycal and a Ca-eugenol cement. Oral Surg Oral Med Oral Pathol 1981; 52: 5311-553.

[21] Trigo FJ. Patología sistémica veterinaria, pp 109-118. México: Mc Graw-Hill Interamericana, 1998.

[22] Ranly DM. Pulpotomy therapy in primary teeth: new modalities for old rationales. Pediatr Dent 1994; 16: 403-9.

[23] Ranly DM, Fulton R. Reaction of rat molar pulp tissue to formocresol, formaldehyde and cresol. J Endod 1976; 2: 
176-81.

[24] García-Godoy F, Novakovic DP, Carvajal IN. Pulpal response to different application times of formocresol. J Pedod 1982; 6: 176-93.

[25] Berman C, Massler M. Experimental pulpotomies in rat molars. J Dent Res 1958; 3:229.

[26] Magnusson BO. Therapeutic pulpotomies in primary molars with the formocresol technique. Acta Odontol Scand 1978; 36 : 157-65.

[27] Alacam A. Pulpal tissue changes following pulpotomies with formocresol, glutaraldehyde-calcium hydroxide, glutaraldehyde-zinc oxide eugenol pastes in primary teeth. J Pedod 1989; 13: 123-32.

[28] Fuks AB, Bimstein E, Bruchim A. Radiographic and histologic evaluation of the effect of two concentrations of formocresol on pulpotomized primary and young permanent teeth in monkeys. Pediatr Dent 1983; 5: 9-13.

[29] Markowitz K, Moynihau M, Liu M, et al. Biologic properties of eugenol and zinc oxide-eugenol. Oral Surg Oral Med Oral Pathol 1992; 73: 729-37.

[30] Wright KJ, Barbosa SV, Araki K, et al. In vitro antimicrobial and cytotoxic effects of kri 1 paste and zinc oxide-eugenol used in primary tooth pulpectomies. Pediatr Dent 1994; 6: 102-5.

[31] Rushman M, Rahim A. Diffusion of buffered glutaraldehyde and formocresol from pulpotomized primary teeth. J Dent
Child 1992; 59: 108-10.

[32] Myers DR, Pashley DH, Whitford GM, McKinney RV. Tissue changes induced by the absorption of formocresol from pulpotomy sites in dogs. Pediatr Dent 1983; 5: 6-8.

[33] Ranly DM, Horn D. Assessment of the systemic distribution and toxicity of formaldehyde following pulpotomy treatment: part two. J Dent Child 1987; 54: 40-4.

[34] Physicochemical characterization of Lyophilized bovine bone grafts. Galia CR, Lorenco AL, Rosito R, Souza CA, Camago LM. Rev Bras Ortop 2015; 46: 444-51.

[35] Fontana F, Rocchieta I, Dellavia C, Nevins M, Simion M. Biocompatibility andmanageability of a new fixable bone graft for the treatment of localized bone defects: preliminary study in a dog model. Int J Periodontics Restorative Dent 2008; 28: 601-7.

[36] Naik S, Hedge AM. Mineral trioxide aggregate pulpotomies: a case series outcomes assessment. J Am Dent Assoc 2006; 137: $610-8$.

[37] Moretti AB, Sakai VT, Oliveira TM, Fornetti AP, Santos CF, Machado MA. The effectiveness of mineral trioxide aggregate, calcium hydroxide and formocresol for pulpotomies in primary teeth. Int Endod J 2008; 41(7): 547-55.

[38] Srinivasan D, Jayanthi M. Comparative evaluation of formocresol and mineral trioxide aggregate as pulpotomy agents in deciduous teeth. Indian J Dent Res 2011; 22: 385-90. 